\title{
Issues in implementation of fixed time fixed price software projects: an Indian case
}

\section{Mohammed Arshad Khan*}

\author{
Sapient Corporation, \\ NOIDA Oxygen Boulevard, \\ Tower C, First Floor, Plot No. 7, \\ Sector 144 Expressway, \\ NOIDA 201301, UP, India \\ Email: mkhan11@sapient.com \\ *Corresponding author
}

\section{Santanu Roy}

Institute of Management Technology, UG-02 Dubai International Academic City, P.O. Box 345006, Dubai, United Arab Emirates Email: sroy@imtdubai.ac.ae

\begin{abstract}
Fixed Time Fixed Price (FTFP) is a software project engagement model wherein the scope of the software deliverables, budget, and schedule, are decided upfront before the commencement of the project. The work reported in the paper probes into the factors perceived to be influencing the effectiveness of such project engagements in Indian information technology companies. The respondents comprise the developers and the quality assurance teams belonging to both junior and senior levels. Results indicate that client acceptance, perceived benefits to the project organisation, and delegation of authority, and, to some extent, project goals and top management support, are significant factors for project implementation success. Development and quality assurance teams perceive issues such as project goals and benefits to the project organisations similarly though differing significantly regarding the issue of client acceptance. Junior and senior team members exhibit perception differences only on the issue of top management support in crisis.
\end{abstract}

Keywords: fixed price; fixed time; software; information technology; project implementation effectiveness.

Reference to this paper should be made as follows: Khan, M.A. and Roy, S. (2014) 'Issues in implementation of fixed time fixed price software projects: an Indian case', Int. J. Intercultural Information Management, Vol. 4, No. 1, pp.67-86.

Biographical notes: Mohammed Arshad Khan is currently serving as a Project Manager in Sapient Corporation, based out of Noida. Prior to joining Sapient, he was a Lead Consultant in Headstrong, Noida. He earlier served as a Research Engineer in ABB's Indian and Swedish corporate research centres in Bangalore and Vasteras. He has more than ten years of IT industry experience spread over wide variety of business functions. He is currently pursuing his $\mathrm{PhD}$ at $\mathrm{AMU}$. His prime areas of interest are software process improvement, software contracting, knowledge and IT project management. He holds a Master's degree in Computer Applications from Bangalore University. 
Santanu Roy is currently a Professor in Operations, Supply Chain and Technology Management at the Institute of Management Technology (IMT), Dubai. He has earlier served as the Officiating Dean (Academic Administration) and Professor and Chairperson, Research and Doctoral Programmes at IMT, Ghaziabad, India. Prior to joining IMT, he was a faculty at Vinod Gupta School of Management, Indian Institute of Technology (IIT) Kharagpur. He had earlier served as a Senior Scientist in NISTADS, CSIR, New Delhi. He is a PhD from IIT Kharagpur and MS from IIT Delhi. He has more than 28 years of experience in research and teaching.

This paper is a revised and expanded version of a paper entitled 'Probing the factors influencing the effectiveness of fixed time fixed price software project implementation: case of an Indian IT company' presented at the 'PMI India Research and Academic Conference', Indian Institute of Technology Madras, Chennai, India, 31 January-2 February 2013.

\section{Introduction}

In the context of Indian information technology (IT) companies that are primarily into offshore outsourcing services, the software project execution is broadly done via two engagement modes: the time and materials (T\&M) mode, commonly known as the cost plus model, and fixed time fixed price (FTFP) mode, commonly known as the fixed price model. In T\&M mode of engagement, the IT outsourcing firm provides services for a stipulated period, for instance, a period of six months or a year, at a pre-decided billing rate. In FTFP mode of engagement, deliverables with certain requirements are agreed upon upfront along with the cost and duration of the development effort. The set of constraints and assumptions are also agreed upon upfront. From the project management perspective, in T\&M mode, the delivery or the project ownership lies with the client who is eventually the outsourcer. In FTFP mode, the project ownership lies with the outsourcing company and the client has very little control on the delivery.

In recent years the usage trend of FTFP is increasing in Indian software companies and it is estimated that between $26 \%$ and $54 \%$ of the total revenues of top Indian IT companies are derived from these engagements as evidenced from a perusal of the annual reports of the following companies: Wipro, Infosys, TCS, Cognizant and HCL collectively known as 'WITCH' (Wipro Annual Reports, 2008-2013; Infosys Annual Reports, 2008-2013; TCS Annual Reports, 2008-2013; Cognizant Annual Reports, 2008-2013; HCL Annual Reports, 2008-2013). Given the relevance of this engagement model, there has been no significant study in this area which can ascertain the critical factors which can influence the success of these types of projects and how do the software professionals working in these IT companies perceive these factors and current project management practices. Although many research studies have been conducted for ascertaining critical project success factors, but these are largely generic in nature and thus lack specificity.

There are three critical issues in this discourse that are sought to be addressed by the research work reported in the paper. First, the present work focuses on a specific category of project engagements (FTFP) at the first level of study. The fixed price engagement model has emerged as the dominant project engagement mode in the Indian software industry as enunciated above. Second, the work reported attempts to probe 
project implementation factors from the vendors' perspective, that is, from the perspective of the outsourcing companies that has received limited acknowledgement in the literature. Third, there are two major groups of personnel who work on software projects in any IT firm, namely the developers and the quality assurance teams. Further, these project personnel could belong to either the junior or to the senior category based upon their functional experience and expertise along development or quality assurance tracks. The roles and work routines of these two groups working on software projects are distinctly different. The first set of teams is responsible for developing the software as per client requirements, while the latter are responsible for testing the same software and ensuring that the software is released without any bugs. Ensuring successful coordination among these groups, thus assumes criticality for software project implementation success. Therefore, it becomes imperative to understand how both these groups - the developers and the quality assurance personnel - perceive the importance of the various factors that impact project implementation success. This would help ascertain whether these two major groups of project personnel view important project implementation factors on similar lines or not. This would confirm common success factors for all project scenarios as also the factors viewed differently by the two groups.

The remainder of this paper is organised as follows. The next section presents a literature review on the concept of the project and managing projects, project performance and the relevance of FTFP project engagements. The following sections describe the methodology for the research work carried out, research results and discussion and finally, the conclusion of the study.

\section{Literature review}

\subsection{Project, project management and project performance}

A project is nothing but a unique endeavour to create a product and service with a definite start and an end. Project Management Institute (PMI, 2008, p.5) has defined a project as "A temporary endeavor undertaken to create unique product or service". By virtue of this definition it is quite evident that a project will have a specific timeline for completion, a specific set of goals and a series of complex or interrelated activities. It will also have a limited budget and other resources, including material, technology and human resources for executing the project. According to Slevin and Pinto (1986), a project is considered successful if meets four broad conditions: it is on schedule, within budget, achieves basically all the goals originally set for it, and is accepted and used by the clients for whom the project is intended.

Every project has a certain life cycle that is divided into four distinct stages (Adams and Barndt, 1983; King and Cleland, 1983): conceptualisation, planning, execution, and termination. Conceptualisation is the initial project stage where the preliminary goals and alternatives are defined and the possible means to accomplish these goals are considered. Planning is the second stage which involves the establishment of formal plans to accomplish the initial goal(s) that includes scheduling, budgeting and allocation of resources. Execution is the third stage that involves the actual execution of the work and termination is the fourth stage. Once the project is completed, there are some final activities which must be performed. These activities usually include the release of project resources, transferring projects to the clients, and the reassignment of the project team 
personnel. There are a rich variety of projects all around us, based on the needs and the aspirations of both people and organisations. In fact, projects have been initiated since the earliest civilisations, the Tower of Babel or the Egyptian Pyramids were some of the first projects. PMI (2008) defines project management as the application of knowledge, skills and techniques to execute projects effectively and efficiently. It's a strategic competency for organisations, enabling them to tie project results to business goals - and thus, better their competition in the market. The PMI divides project management into the following process groups: initiating, planning, executing, monitoring, controlling, and closing; and also nine knowledge areas: integration, scope, time, cost, quality, procurement, human resources, communications, and risk management.

In recent years, a number of studies have been carried out in the area of current practices of project management, and on their usage, effectiveness, and performance. Barber (2004) studied the effects of benchmarking project management and project performances. The study concluded that benchmarking project management significantly improves the project performance. Sauer and Reich (2009) studied the need of rethinking project management for the information technology sector and endeavoured to define the direction and extend the domain of IT project management research. Their study proposed two dimensions for further research: the project as a knowledge process, and the project as an emotional process. Other researchers who worked in this area included Winter et al. (2006). Yet another team of researchers has shed light on the current project management practices and the success criteria of projects in three countries: UK, Australia and Canada (Fortune et al., 2011). Respondents at a broad level were found to consider 'on-time', 'on-budget' and 'delivery of benefits' as key success criteria. Kapsali (2011) studied why conventional project management practices lead to the failure of publicly-funded innovation deployment projects and investigated how the use of systems thinking in project management can help projects be more successful. The paper concluded that by using flexibility in planning, communication, controlling activities, and innovation, the projects could become more successful.

Researchers have identified factors such as the convergence of the stakeholders on a common ground, collaboration between the project manager and the stakeholders, and collective ownership of the project by all project participants as the key success criteria of project success (Wateridge, 1995). A small difference of opinion existing among the project stakeholders regarding time or cost or functionality could lead to a large divergence towards the end of the project. Likewise, Turner and Muller (2003) identified high team collaboration between project manager and stakeholders, and the project's collective ownership by all project participants as key success criteria. The authors also identified project manager's empowerment for ownership and guidance as a key feature impacting project success. Researchers on software project management include Plant and Willcocks (2007), Poon and Wagner (2001), Remus and Wiener (2009), Wong and Tein (2004), and Dong et al. (2004). Kuruppuarachchi et al. (2002) have probed into IT project implementation strategies.

Smith et al. (2009) studied how the soft competencies of an IT Project manager could affect the success of a project. The paper concluded after carrying out a qualitative analysis that optimism and stress handling qualities of a project manager could lead to improvements in project outcomes. Karlsen (2011) studied how supportive work culture can lead to efficient management of uncertainty in projects. The paper concluded 
after a study of projects being carried out in Norway that a supportive work culture is an important factor for managing uncertainty in project environments. Adenfelt (2010) studied how shared knowledge, coordination and communication can affect the performance of transnational projects. The study data illustrated how lack of coordination and communication can hamper transnational project performance. It also talked about the double role of effective knowledge management, which can act as a key differentiator as well as a project performance enabler. Another team of researchers studied the relationship between a project team's technical competency and success dimensions of information system projects (Liu et al., 2010). They modelled the link between the general task completion competency and performance of the development teams with two external factors - the contribution of users and controls established by management. The statistical analysis of the sample showed that these two factors are important organisational characteristics that influence project team's task completion competency and thus project management performance. This study, in fact, did extend the research of Aladwani (2002) and Rose et al. (2007) who had suggested that a team's innate ability to complete tasks and also the cumulative competencies of the software development teams are the key factors of project success. Andersen (2010) proposed a new tool named X model for describing and assessing individual projects and it has been used quite extensively in Norway. In this concept, the social subsystem encompasses every human aspect that may impact the work situation and the technical subsystem covers the economic and commercial aspects. The $\mathrm{X}$ model integrated the two approaches into a single and consistent framework.

Cervone (2010) provided a general overview and introduction to agile project management and its effectiveness in managing and controlling the projects. The paper mentions four core principles of agile development: individuals and interactions over processes and tools; working software over comprehensive documentation; customer collaboration over contract negotiations; and responding to changes over following a plan. The agile project management emphasises on two very important factors; risk minimisation by focusing on short iterations of clearly defined deliverables and reducing the communication gap by directly communicating with the end users in the development process. These two factors help the project team to quickly adapt to the rapidly changing and unpredictable requirements. It also enhances the project's acceptability as the end users get to see the functional deliverables very early along the development cycle and thus reduces expectation mismatch.

\subsection{FTFP project engagements}

As mentioned above, software development outsourcing contracts are typically categorised into fixed time fixed price contracts, normally referred to as just fixed price (FP) contracts, and time and materials (T\&M) contracts, also known typically as cost plus (CP) contracts (Banerjee and Duflo, 2000; Gopal et al., 2003; Kalnins and Mayer, 2004). A study report (Radhakrishnan, 2011), described in a white paper named 'IT Offshore Outsourcing in Capital Markets' (published by Headstrong, an Indian IT Consulting firm that works primarily into banking, financial and insurance service (BFSI) vertical), that there are two categories of offshore outsourcing engagements: fixed price and time and materials. In FP contracts, the scope of work and the deliverables are 
agreed upfront along with the time-frame and the cost. The project constraints and assumptions are also decided upfront before the start of the project. In T\&M contracts, the services are provided for a fixed period at a pre-decided rate. The paper also describes some of the known challenges of offshoring and how they impact the project management of offshore outsourcing engagements.

It has been observed that there has been a perceptible shift towards FTFP project engagements (and thus away from T\&M engagements) over the years. In fact, commenting on this particular trend, Bob Whitney, Partner and Director of Ernst \& Young's Chicago Advanced Development Center, said in 1998, "It is changing rapidly as more and more (projects) are going to be delivered in this fashion. It's a trend as clients are asking for it more and we're a lot more comfortable with it, it provides us with potential upside if we beat the time and cost" (Shein, 1998, p.69). Similar sentiments were echoed by Michael Wendrow, Pacific Northwest Unit Delivery Manager for Cap Gemini America, in Portland, Oregon, "We've been doing fixed-price, fixed-time models for several years" (Shein, 1998, p.69). In the Indian context, Banerjee and Duflo (2000), in their seminal work based on data collected on 230 projects in 125 software firms in three major centres of software production in India - Bengaluru, Pune, and Hyderabad have observed that T\&M contracts were the least frequent $(15 \%)$, FP contracts were the most frequent $(58 \%)$, the rest falling into the mixed contracts category. The context is also relevant here as the Indian software industry is maturing from smaller, low-risk projects to high-end systems development projects that are inherently more risky. This trend towards securing FTFP project contracts as against other forms of contractual deals has also received support from the study carried out by Gopal and Sivaramakrishnan (2008). Using data collected on 93 software development projects from an offshore vendor located in India, the results indicate that vendors prefer FTFP contracts when they go for contracts for large projects with long durations and larger teams. Larger and longer projects are often considered more risky. In software parlance, projects characterised by higher intangibility and evaluation difficulty characterise riskier ventures (Kalnins and Mayer, 2004). Dey et al. (2007) have attempted to develop a risk management framework for software development projects. The issues related to greater perceived software project risk also comprise a greater possibility of change in specifications (Nidomolu, 1995), code complexity and multiple modules (Barki et al., 1993), and costly and difficult client interactions (Carmel and Agarwal, 2002). The issue of the type of contract selection might impact project success as pointed out by Nguyen et al. (2004) in their study of project success factors in large construction projects in Vietnam.

The data presented in Table 1 exemplify the above in no uncertain measure. From a perusal of the Annual Reports of 'WITCH' for the past seven years, from 2008 till 2013, it is observed that $26 \%$ to $54 \%$ of the revenue of the top five Indian IT companies listed on NASDAQ, that is, Wipro, Infosys, TCS, Cognizant and HCL, are derived from fixed price engagements (Wipro Annual Reports, 2008-2013; Infosys Annual Reports, 20082013; TCS Annual Reports, 2008-2013; Cognizant Annual Reports, 2008-2013; HCL Annual Reports, 2008-2013).

There is a great deal of literature on the relative merits and demerits of the two major types of contracts. It has been observed that the type of contract has a bearing upon the vendor's profitability in outsourced projects (Ethiraj et al., 2005; Gopal and Koka, 2010). Bajari and Tadelis (2001) were of the opinion that a cost plus contract was preferred to a fixed price contract when a project was more complex. According to Bryde and Joby 
(2007, p.144), “The fixed price contract has the perceived advantage, from the client's perspective, of transferring the risk of project overruns to the contractor, so fixed price contracts and competitive bidding rapidly became common practice". In the same vein, Gopal and Koka (2010) have opined that since FTFP contracts have a fixed cap of revenues from the project, so there is an incentive for the vendor to be more efficient (Arora and Asundi, 1999) to lower the costs (Kalnins and Mayer, 2004) and also become more effective. Further, there is a point of view that capable and reputed vendors prefer higher-risk FTFP contracts for some projects with the prospect of getting higher returns (Lichtenstein, 2004; Ethiraj et al., 2005). An important consideration for reduction in project uncertainty for the vendor is the learning that is accrued from previously completed projects from the same client (Corts and Singh, 2004). Gopal and Koka (2010) carried out a study on software development outsourcing industry in India based on a random sample of 120 projects with data available from 100 completed projects carried out by a leading Indian vendor for offshore clients. The aim of their work was to ascertain how different incentive structures in the two categories of FTFP and T\&M projects influence the quality of work provided by the vendor. The results indicate that the vendor realised significantly higher margins from T\&M than FTFP projects, whereas the quality of FTFP projects were found to be significantly better compared to T\&M projects. It was also observed that the lack of trained personnel was a significant factor affecting quality of a project engagement, and for FTFP projects, there was a strong positive relationship between quality and margins. Further, the authors suggested that in FTFP projects, client monitoring has little impact as strong incentives on the vendor induced self-monitoring.

Table 1 Revenue contribution of fixed price projects in overall revenues

\begin{tabular}{lcccccc}
\hline $\begin{array}{c}\text { Annual report of } \\
\text { year/organisations }\end{array}$ & 2008 & 2009 & 2010 & 2011 & 2012 & 2013 \\
\hline Wipro & $34 \%$ & $41.50 \%$ & $45.73 \%$ & $45.70 \%$ & $46.40 \%$ & $49.40 \%$ \\
Infosys & $35.40 \%$ & $38.50 \%$ & $40.30 \%$ & $39.30 \%$ & $40 \%$ & $40.80 \%$ \\
TCS & $44.8 \%$ & $47.8 \%$ & $49.4 \%$ & $47.4 \%$ & $47.2 \%$ & $52.0 \%$ \\
Cognizant & $26.70 \%$ & $30.30 \%$ & $31.50 \%$ & $31.70 \%$ & $33.10 \%$ & $34.00 \%$ \\
HCL & $37.20 \%$ & $40.30 \%$ & $41.80 \%$ & $49.20 \%$ & $51 \%$ & $54 \%$ \\
\hline
\end{tabular}

Source: Wipro annual reports, Infosys annual reports, TCS annual reports, Cognizant annual reports, HCL annual reports

\section{Methodology}

\subsection{Research objective and framework}

The main objective of the present research study was to study the perception of project teams towards project management implementation effectiveness factors in fixed price fixed time software projects. The study focused on the key aspects of project mission, the role of top management support and project performance along with their indicators for project management effectiveness and thus project success. 
The research objective is in line with the available literature on this subject following the broad framework developed by Pinto and Slevin (1987b, 1988a, 1988b, 1988c) and Pinto and Prescott $(1988,1990)$ wherein ten critical success factors were identified, empirically based upon a database of over 400 projects: project mission, top management support, project schedule/plan, client consultation, personnel, technical tasks, client acceptance, monitoring and feedback, communication, and troubleshooting. Muller and Jugdev (2012) have carried out a detailed analysis of this framework. Regarding project success factors, The Standish Group (1994) had carried out a pioneering work detailed in their CHAOS Report according to which the top five project success factors are user involvement, top management support, clear requirements, proper planning and realistic expectations. Client acceptance or customer satisfaction with the project outcomes is an important critical success factor (Zwikael and Globerson, 2006; Kerzner, 2006). Dvir et al. (2006), however, caution that different project scenarios might require different treatment and approaches to be followed. Jiang et al. (1996) observed that clearly defined project goals (Plant and Willcocks, 2007; Remus and Wiener, 2009; Mathrani and Viehland, 2010), skilled project manager, top management support (Fortune and White, 2006; Zwikael, 2008a), competent team members, and availability of required resources are the top five success actors for information systems projects. A literature review on what constitutes project success has been carried out by Prabhakar (2008). In the same vein, Sudhakar (2012) has carried out an extensive literature survey of software project success factors and have identified the following significant ones: communication in project, top management support, clear project goal, reliability of output, project planning, teamwork, project team coordination, quality control, client acceptance, accuracy of output, reduce ambiguity, maximise stability, realistic expectations, and user involvement. Top management involvement is critical for project success. In a crosscountry study of software industry, Zwikael (2008b) have identified ten critical top management support processes: appropriate project manager assignment, refreshing project procedures, involvement of the project manager during initiation stage, communication between the project manager and the organisation, existence of project success measurement, supportive project organisational structure, existence of interactive inter-departmental project groups, organisational projects resource planning, project management office (PMO) involvement, and use of standard project management software.

A critical and scarce resource in software development projects is the availability of trained project personnel (Krishnan et al., 2000; Gopal and Koka, 2010). Yet another important factor that might impinge on project success is making sure that adequate requirement analysis and design are carried out at the beginning of the project (Krishnan et al., 2000; Ravichandran and Rai, 2000; Gopal and Koka, 2010). Nixon et al. (2012) have focused their study on leadership performance and its relation to project success or failure. Andersen et al. (2006) have observed in their study that the most important factors in improving managerial ability to deliver results in time and at cost (and thus very relevant to FTFP projects) were strong project commitment, early stakeholder influence, stakeholder endorsement of project plans, and rich project communications.

As much important as the success studies are the ones that delineate why projects fail (Pinto and Mantel, 1990). It has been estimated that problems derived from unsuccessful software projects did cost US companies and government agencies about US\$ 145 B 
annually (Jiang et al., 2004). Boyd (2001), quoting an earlier report in The Guardian, has stated that the British government had wasted more than $£ 1 \mathrm{~B}$ in high-profile government IT failures since the mid-1990s. Jorgensen and Molokken-Ostvold (2006) have estimated that the average cost overruns in software projects is about $33 \%$. A pioneering work in this area was KPMG's 1997 survey of unsuccessful information technology projects involving 1450 public and private sector organisations in Canada (Whittaker, 1999). The results revealed that the three most common reasons for project failure are: poor project planning, a weak business case, and the lack of top management involvement and support. It was also observed that project failures are more likely due to schedule overruns rather than budget overruns, and that project failures might also be a result of new or unproven technology usage, poor estimates or weak requirements analysis at project planning stage, and the inability of the vendors to meet commitments.

\subsection{Organising the research case study}

The research site for the work reported in the paper is one of the top information technology companies that have major offshore delivery centres in India. The company adopts the global delivery model (GDM) for its delivery and provides business technology solutions and consulting services. Gartner defines GDM to encompass a 'focus on the technical skills, process rigour, tools, methodologies, overall structure and strategies for seamlessly delivering IT-enabled services from global locations' (Wikipedia, 2014). The firm uses the global distributed delivery of project development wherein the project execution team is scattered across multiple geographic locations (Ghosh and Vergese, 2004). The software firm also uses an agile development methodology (Cervone, 2010) as the preferred software development model. The parent company with its headquarter in the USA is a major global integrated marketing and technology services firm, and was named one of the top 50 fastest growing companies by Fortune magazine in 2010, that was a 43 spot improvement over its 2009 rank. The software firm has got very good execution track record of FTFP project engagements. The leading position of this company can be judged from the fact that the company has achieved success for their clients at more than three times the industry average. In 2005, $93 \%$ of engagements were completed on or ahead of schedule, the industry average being $29 \%$ (The Standish Group, 2004). However, for reasons of confidentiality, the identity of the company cannot be revealed.

\subsection{Sampling, research design and analysis}

The research carried out was exploratory in nature with an empirical approach. The questionnaire was adapted from Project Implementation Profile (Slevin and Pinto, 1986; Pinto and Slevin, 1987a). The detailed framework of this body of work along with other relevant literature on the subject has been discussed above. Every respondent who was considered for this survey had a minimum of one year experience in FTFP software project development. A sample size of 41 was initially considered for carrying out this survey. The respondents were selected from four different projects - all of these were FTFP projects and were known to have incurred huge budget and time overruns. The overall software project development experience ranged from one to 12 years. The 
survey excluded the leadership team and managers and focused more on the developers, senior developers, project leads and testers since they are the key people for delivery execution. Usable data were collected from 33 team members who responded to the survey, representing various career stages and operational areas of software development and quality assurance. Eight team members did not respond to the survey. The teams were classified into two levels: first as developers and the quality assurance (QA) personnel; and second, as senior and junior team members. The questionnaire comprised questions that tapped the perception of the respondents towards factors such as project goals, project management benefits to the organisation, top management support in a crisis, delegation of authority, project scheduling, budget, client acceptance, and development process effectively. Each of the questions was framed on seven-point Likert scale with 1 representing 'strongly disagree' and 7 representing 'strongly agree'. The team members were asked to rate each item in terms of how important each question was for project implementation.

The team members in software projects form two broad categories of personnel: developers and quality assurance personnel or the testers. The personnel across both the above groups could further belong to either the senior or the junior category. For the purpose of analysis, first, the perceived importance of the various project implementation success factors across all categories of project personnel have been ascertained to help identify the high importance factors as also the factors with average or low importance. Second, in order to verify whether there are differences in perception on the various project implementation effectiveness factors among these groups of project personnel, the methodology of analysis of variance (ANOVA) has been adopted. Since this was a first level exploratory study on issues influencing FTFP project engagements in the Indian software industry scenario that is expected to open up avenues for further research in the area, no hypothesis has been proposed.

\section{Results and discussion}

Table 2 presents the mean values and corresponding of standard deviations of the various project implementation factors as perceived by developers, quality assurance personnel, and senior and junior team members.

Analysing Table 2, the following are observed. The concept of 'project scheduling' has universally received average to low response from all respondents. This might be a result of the fact that the project schedules are fixed in FTFP contracts from the beginning, and thus, it appears not to have a great bearing on project implementation. It might also reflect the situation where the overall schedules are decided by the top management with little participation by project team members. Interestingly, the developers' perception on this factor is the lowest lending support to the latter reasoning. Likewise, 'development process effectiveness' as also 'project budget' universally received average to low response. One requires further study to probe into this unlikely result as logically the effectiveness of the development process has a huge bearing on project implantation success. Perhaps the low/average perception towards project budget could be explained along the same lines as that of project scheduling, both being given issues, decided at the time of signing FTFP project contracts. 
Table 2 Respondents' perception on factors of project implementation effectiveness

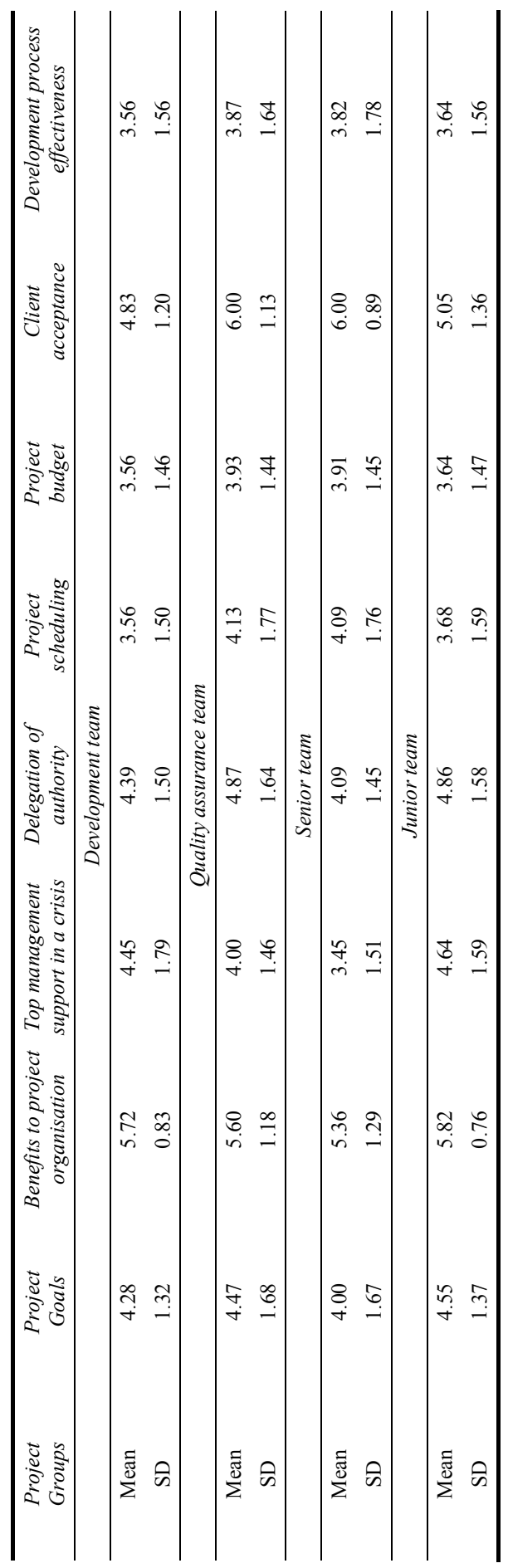


Interestingly, the development teams and the senior team members are not particularly satisfied with 'top management support in crises' whereas the testers and the junior team members seem to be the more satisfied lot. Perhaps the senior team members really have to bear the brunt of whatever might go wrong in a crisis situation and they feel a perceptible lack of support from the top management should such a situation arise. This really is a cause for concern for FTFP project management in Indian IT companies. Further, only the senior team members do not feel particularly pleased with 'delegation of authority' whereas all other groups seem to be satisfied with the level of delegation of authority in the organisation. It is quite apparent from this result that there probably exists a clearly defined delegation of authority structure across the different category of project personnel in the organisation. Does the result that the senior personnel are not particularly happy with the concept of delegation of authority indicate that these members are averse to this concept? At the same time, what is gratifying is to observe that 'benefits to project organisation', 'client acceptance' and to some extent 'project goals', all significant factors for project implementation success, are perceived highly by all categories of respondents surveyed (except an average score for 'project goals' by the senior team members). All project team personnel are in agreement that client acceptance and unanimity on project goals as also selecting projects that bring benefits to the project organisation as a whole, are important success factors for FTFP projects. All these results are along expected lines.

The statistical analysis of variance (ANOVA) of the respondents' responses to the survey exhibited the results that follow.

Table 3 presents the ANOVA results on the issue of 'project goals' with respect to development teams and quality assurance teams and Table 4 presents ANOVA results for the same groups of project personnel on the issue of 'benefits to the parent organisation'. It is observed that there are no significant differences between the perceptions of the development personnel and the quality assurance personnel towards project goals as observed from Table 3 . The $\mathrm{F}$ value is 0.131 which is insignificant.

Table 3 Project goals and development teams/quality assurance teams

\begin{tabular}{lccccc}
\hline & Sum of squares & $d f$ & Mean square & $F$ & Sig. \\
\hline Between Groups & .292 & 1 & .292 & .131 & .720 \\
Within Groups & 69.344 & 31 & 2.237 & & \\
Total & 69.636 & 32 & & & \\
\hline
\end{tabular}

Similarly, from a perusal of Table 4 it is evident ( $F$ value of 0.121 ) that there are no significant differences in perceptions on the issue of 'benefits to the parent organisation' between the development and the quality assurance personnel.

Table 4 Benefits to the parent organisation and development teams/quality assurance teams

\begin{tabular}{lccccc}
\hline & Sum of squares & $d f$ & Mean square & $F$ & Sig. \\
\hline Between Groups & .122 & 1 & .122 & .121 & .730 \\
Within Groups & 31.211 & 31 & 1.007 & & \\
Total & 31.333 & 32 & & & \\
\hline
\end{tabular}

Thus, for both the above factors, it is observed that no significant differences in perception exist between the two groups regarding these factors. 
The project goals permeate the entire project and have similar implications for both the developers and the testers. The two groups also appear to have perceived common business benefits being leveraged by the vendor out of these projects, hence no significant perception differences have been observed between these groups regarding project goals and the benefits to the parent organisation.

Table 5 presents the ANOVA results on the issue of 'top management support in a crisis' with respect to senior and junior team members. Similarly, Tables 6, 7, 8 and 9 present the ANOVA results for the same groups of project personnel on the issues of 'delegation of authority', 'project scheduling', 'project budget', and 'development process effectiveness' respectively.

A perusal of Table 5 points out to the existence of significant differences in perception regarding the issue of top management support in a crisis between the junior and the senior project team members.

Table 5 Top management support in a crisis and senior/junior team members

\begin{tabular}{lccccc}
\hline & Sum of Squares & $d f$ & Mean Square & $F$ & Sig. \\
\hline Between Groups & 10.242 & 1 & 10.242 & 4.188 & .049 \\
Within Groups & 75.818 & 31 & 2.446 & & \\
Total & 86.061 & 32 & & & \\
\hline
\end{tabular}

The $\mathrm{F}$ value for Table 5 is 4.188 which is significant. This perception difference might have resulted from low levels of direct interactivity between the junior project team members and that of the leadership teams. It may be pertinent to note here that in most of the information technology-based organisations, communication between the junior team members and project leadership team often take place via the senior team members, more specifically the track leads who normally communicate directly with the top management. Consequently, the junior team members might not be in full knowledge of the exact extent and depth of communication between the top management and the track leads. Therefore, this communication gap could be a potential source of perception differences arising between the two groups of project personnel regarding the issue of top management support in a crisis.

Table 6 reveals that there is no significant difference in perception between the junior and the senior project team members regarding the issue of delegation of authority (F value is 1.847).

Table 6 Delegation of authority and senior/junior team members

\begin{tabular}{lccccc}
\hline & Sum of Squares & $d f$ & Mean Square & $F$ & Sig. \\
\hline Between Groups & 4.379 & 1 & 4.379 & 1.847 & .184 \\
Within Groups & 73.500 & 31 & 2.371 & & \\
Total & 77.879 & 32 & & & \\
\hline
\end{tabular}

The fact that there is no significant difference in perception as observed in Table 6 might have resulted from clear segregation of roles and responsibilities defined for each team member carrying out the project, eventually leading to fewer conflicts within the teams. In most of the IT organisations the project teams are divided into different functional tracks, that is, the functional tracks of business analysis, development, and quality assurance. The different tracks need to collaborate closely in order to deliver any 
software functionality. The business analysis track needs to gather requirements, the development track needs to implement or fix the requirements, and the quality assurance track needs to test or validate the functionality vis-à-vis the project requirements. By virtue of clear roles and responsibilities there are fewer conflicts within various tracks in terms of delivery ownership and accountability of tasks. This points out to the existence of good intra-track collaboration and hence improved project execution.

A perusal of Tables 7, 8 and 9 reveal that there are no significant differences between the perceptions of the junior and the senior project team members towards the important issues of project scheduling, project budget, and development process effectiveness. The $\mathrm{F}$ values of project scheduling, project budget and development process effectiveness are 1.030, 0.554 and 0.299 , and all these are all insignificant.

Table 7 Project scheduling and senior/junior team members

\begin{tabular}{lccccc}
\hline & Sum of Squares & $d f$ & Mean Square & $F$ & Sig. \\
\hline Between Groups & 2.731 & 1 & 2.731 & 1.030 & .318 \\
Within Groups & 82.178 & 31 & 2.651 & & \\
Total & 84.909 & 32 & & & \\
\hline
\end{tabular}

Table 8 Project budget and senior/junior team members

\begin{tabular}{lccccc}
\hline & Sum of Squares & $d f$ & Mean Square & $F$ & Sig. \\
\hline Between Groups & 1.168 & 1 & 1.168 & .554 & .462 \\
Within Groups & 65.378 & 31 & 2.109 & & \\
Total & 66.545 & 32 & & & \\
\hline
\end{tabular}

Table 9 Development process effectiveness and senior/junior team members

\begin{tabular}{lccccc}
\hline & Sum of Squares & $d f$ & Mean Square & $F$ & Sig. \\
\hline Between Groups & .792 & 1 & .792 & .299 & .589 \\
Within Groups & 82.178 & 31 & 2.651 & & \\
Total & 82.970 & 32 & & & \\
\hline
\end{tabular}

The above results are on expected lines primarily because of the nature of FTFP projects. The task of scheduling the project and estimating the project budget are out of the realm of the activities of individual teams working on these projects and are decided up front. The project budget gets finalised at the level of project contract sign-on, and thereafter, the project schedule is concretised based on the high-level project milestones mentioned in the contract. Likewise, the project methodology and the development processes to be adopted for project execution and implementation are agreed upfront. Thus, the project teams themselves do not have much influence over these decisions. The onus for initiating any changes in budget, schedule and development processes lie with the project manager(s) and the stakeholders. Further, these issues are common for the entire project team. This perhaps explains why no significant perception differences exist among the different hierarchy of team members towards project performance indicators of budget, schedule and development process effectiveness. 
Table 10 presents the ANOVA results on the issue of 'client acceptance' with respect to development teams and quality assurance teams working on the project. Table 10 makes it evident that there is a significant difference in perception regarding the issue of client acceptance between the development teams and the quality assurance teams ( $F$ Value is 8.123).

Table 10 Client acceptance and development teams/quality assurance teams

\begin{tabular}{lccccc}
\hline & Sum of Squares & $d f$ & Mean Square & $F$ & Sig. \\
\hline Between Groups & 11.136 & 1 & 11.136 & 8.123 & .008 \\
Within Groups & 42.500 & 31 & 1.371 & & \\
Total & 53.636 & 32 & & & \\
\hline
\end{tabular}

The above results are quite significant. It may be pertinent to note here that the developers are generally more aligned with the clients and, on most occasions, they become an integral part of the requirement generation and consolidation phases of the project. Thus, they understand and appreciate the client needs with much more clarity as compared to the testers. The quality assurance teams or the testers are introduced at a later stage in the development cycle. The basis for the test case script generation is the baseline requirement document. The interactions among the testers and the clients are also very limited, therefore, and mostly confined to query resolutions. The aforementioned reasons, possibly explain the significant differences in perception on the issue of client acceptance between the developers and the quality assurance personnel.

\section{Conclusions}

The 'given' issues in FTFP project management, such as the project schedule and budget have received a low to average response and predictably so. The reason why the dimension of development process effectiveness has been considered as a low priority item by all categories of project personnel requires to be further studied and probed. Interestingly, the senior project personnel do not think highly of the concept of delegation of authority. They also clearly perceive that they receive little top management support during crisis situations. These are points of serious concern for FTFP project management.

A few pointers are particularly noteworthy. Project dimensions such as acceptance of project deliverables by the client, benefits accruing out of working on the projects to the organisation as a whole, and unanimity on project goals, are all considered important for FTFP project implementation success. However, there seem to exist significant differences in perception on the topic of client acceptance between the developers and the testers. This is a critical project implementation effectiveness factor, and, therefore, a differing perception on client acceptance of project outcomes, resulting from different goal alignments between these groups, might impact project success.

No significant differences in perception have been observed between the senior and the junior team members with regards to a majority of the key factors for effective project implementation in FTFP software engagements. However, these two groups within the project teams exhibit significant differences in perception on the important dimension of top management support in a crisis. It may be noted in this context that the juniors are mostly operational people working on the projects. They are overseen 
by the seniors who are primarily accountable for quality, timeliness and the cost of the deliverables. The junior team members have little direct client interaction. Communication from the project leadership normally travels via the seniors in the project teams. Therefore, there is perhaps a possibility of communication gaps between these groups arising out of this process, and this could have led to differing perceptions regarding the issue of top management support in a crisis situation.

The projects considered in this survey were from a single business unit, predominantly working in capital and commodity market technology services domain. The requirement of the software projects in this particular domain keeps changing very rapidly and significantly. This might have an adverse impact upon software project development task execution that, in turn, might affect project management efficiency as suggested by Liu et al. (2010). The study could be further extended to other Indian IT companies adopting FTFP for software project development in various other business verticals such as telecom and healthcare in order to arrive at a more generalised conclusion. Therefore, a very important area for further research could be measuring the execution efficiency and success rate of these types of engagements. Given that new avenues for outsourcing are emerging across the globe, it is very important for the Indian IT industry to mature and optimise its delivery processes so that these companies may continue to maintain their competitive advantage over other outsourcing competitors.

There are limitations to this study, as with any survey-based one. The success variables in the current study are perception-based, and are not based upon objective measures. Further, the respondents were asked to respond to the questions considering only their recently-completed projects, adding to the possibility of bias creeping into the survey methodology. Still, all accepted procedures to collect and validate data have been faithfully followed in the present study, giving credibility to study results and conclusions. There is clearly a scope for further research on the subject. This may include, first, exploring causal relationships among the important factors identified in the study, and second, expanding the scope of the work to include T\&M project engagements as well. This would be helpful in finding out whether significant differences exist, if any, between the two major forms of project contracts as regards project implementation effectiveness factors.

\section{References}

Adams, J.R. and Barndt, S.E. (1983) 'Behavioral Implications of project life cycle', in Cleland, D.I. and King, W.R. (Eds): Project Management Handbook, Van Nostrand Reinhold, New York, pp.222-244.

Adenfelt, M. (2010) 'Exploring the performance of transnational projects: shared knowledge, coordination and communication', International Journal of Project Management, Vol. 28, No. 6, pp.529-538.

Aladwani, A.M. (2002) 'An integrated performance model of information systems projects', Journal of Management Information Systems, Vol. 19, No. 1, pp.185-210.

Andersen, E.S. (2010) 'The X model - a tool for describing and assessing individual projects', International Journal of Managing Projects in Business, Vol. 3, No. 3, pp.369-386.

Andersen, E.S., Birchall, D., Jessen, S.A. and Money, A.H. (2006) 'Exploring project success', Baltic Journal of Management, Vol. 1, No. 2, pp.127-147. 
Arora, A. and Asundi, J. (1999) 'Quality certification and the economics of contract software development: a study of the Indian software service companies', NBER Conference on Organisation Change and Performance, Santa Rosa, CA.

Bajari, P. and Tadelis, S. (2001) 'Incentives versus transaction costs: a theory of procurement contracts', RAND Journal of Economics, Vol. 32, No. 3, pp.387-407.

Banerjee, A.V. and Duflo, E. (2000) 'Reputation effects and the limits of contracting: a study of the Indian software industry', The Quarterly Journal of Economics, Vol. 115, No. 3, pp.989-1017.

Barber, E. (2004) 'Benchmarking the management of projects: a review of current thinking', International Journal of Project Management, Vol. 22, No. 4, pp.301-307.

Barki, H., Rivard, S. and Talbot, J. (1993) 'Toward an assessment of software development risk', Journal of Management Information Systems, Vol. 10, No. 2, pp.203-225.

Boyd, A. (2001) 'The five maxims of project satisfaction', ASLIB Proceedings, Vol. 53, No. 10, pp.423-430.

Bryde, D.J. and Joby, R. (2007) 'Incentivising project performance in the construction of new facilities: utilizing the earned value-based method', Journal of Facilities Management, Vol. 5, No. 2, pp.143-149.

Carmel, E. and Agarwal, R. (2002) 'The maturation of offshore sourcing of information technology work', MIS Quarterly Executive, Vol. 1, No. 2, pp.65-78.

Cervone, H.F. (2010) 'Managing digital libraries: the view from 30,000 feet: understanding agile project management methods using Scrum', OCLC Systems \& Services: International Digital Library Perspectives, Vol. 27, No. 1, pp.18-22.

Cognizant Annual Reports (2008-2013) Available online at: http://investors.cognizant.com/index. php? $\mathrm{s}=120$ (accessed on 30 June 2014).

Corts, K.S. and Singh, J. (2004) 'The effect of repeated interaction on contract choice: evidence from offshore drilling', Journal of Law, Economics and Organization, Vol. 20, No. 1, pp.230-260.

Dey, P.K., Kinch, J. and Ogunlana, S.O. (2007) 'Managing risk in software development projects: a case study', Industrial Management \& Data Systems, Vol. 107, No. 2, pp.284-303.

Dong, C., Chuah, K.B. and Zhai, L. (2004) 'A study of critical success factors of information system projects in China', Proceedings of PMI Research Conference, 11-14 July, London.

Dvir, D., Sadeh, A. and Malach-Pines, A. (2006) 'Projects and project managers: the relationship between project managers' personality, project types, and project success', Project Management Journal, Vol. 37, No. 5, pp.36-48.

Ethiraj, S.K., Kale, P., Krishnan, M.S. and Singh, J.V. (2005) 'Where do capabilities come and how do they matter? A study in the software services industry', Strategic Management Journal, Vol. 26, No. 1, pp.25-45.

Fortune, J. and White, D. (2006) 'Framing of project critical success factors by a systems model', International Journal of Project Management, Vol. 24, No. 1, pp.53-65.

Fortune, J., White, D., Jugdev, K. and Walker, D. (2011) 'Looking again at current practice in project management', International Journal of Managing Projects in Business, Vol. 4, No. 4, pp.553-572.

Ghosh, P.P. and Vergese, J.C. (2004) 'Globally distributed product development using a new project management framework', International Journal of Project Management, Vol. 22, No. 8, pp.669-678.

Gopal, A. and Koka, B.R. (2010) 'The role of contracts on quality and returns to quality in offshore software development outsourcing', Decision Sciences, Vol. 41, No. 3, pp.491-516.

Gopal, A. and Sivaramakrishnan, K. (2008) 'Research note: on vendor preferences for contract types in offshore software projects: the case of fixed price vs. time and materials contracts', Information Systems Research, Vol. 19, No. 2, pp.202-220. 
Gopal, A., Sivaramakrishnan, K., Krishnan, M.S. and Mukhopadhyay, T. (2003) 'Contracts in offshore software development: an empirical analysis', Management Science, Vol. 49, No. 12, pp.1671-1683.

HCL Annual Reports (2008-2013) Available online at: http://www.hcltech.com/investors/resultsreports (accessed on 25 June 2014).

Infosys Annual Reports (2008-2013) Available online at: http://www.infosys.com/investors/ reports-filings/annual-report/Pages/annual-reports.aspx (accessed on 27 June 2014).

Jiang, J.J., Klein, G. and Balloun, J. (1996) 'Ranking of system implementation success factors', Project Management Journal, Vol. 27, No. 4, pp.49-53.

Jiang, J.J., Klein, G., Hwang, H.G., Huang, J. and Hung, S.Y. (2004) 'An exploration of the relationship between software development project maturity and project performance', Information and Management, Vol. 41, No. 3, pp.279-288.

Jorgensen, M. and Molokken-Ostvold, K. (2006) 'How large are software cost overruns? A review of the 1994 CHAOS report', Information and Software System, Vol. 48, No. 4, pp.297-301.

Kalnins, A. and Mayer, K.J. (2004) 'Relationships and hybrid contracts: an analysis of contract choice in information technology', Journal of Law, Economics and Organization, Vol. 20, No. 1, pp.207-229.

Kapsali, M. (2011) 'Systems thinking in innovation project management: a match that works', International Journal of Project Management, Vol. 29, No. 4, pp.396-407.

Karlsen, J.T. (2011) 'Supportive culture for efficient project uncertainty management', International Journal of Managing Projects in Business, Vol. 4, No. 2, pp.240-256.

Kerzner, H. (2006) Project Management: A Systems Approach to Planning, Scheduling and Controlling, 9th ed., Wiley, NY.

King, W.R. and Cleland, D.I. (1983) 'Life cycle management', in Cleland, D.I. and King, W.R. (Eds): Project Management Handbook, Van Nostrand Reinhold, New York, pp.209-221.

Krishnan, M.S., Kriebel, C.H., Kekre, S. and Mukhopadhyay, T. (2000) 'An empirical analysis of productivity and quality in software products', Management Science, Vol. 46, No. 6, pp.745-759.

Kuruppuarachchi, P.R., Mandal, P. and Smith, R. (2002) 'IT project implementation strategies for effective changes: a critical review', Logistics Information Management, Vol. 15, No. 2, pp.126-137.

Lichtenstein, Y. (2004) 'Puzzles in software development and contracting', Communications of the $A C M$, Vol. 47, No. 2, pp.61-65.

Liu, J., Chen, H., Jiang, J.J. and Klein, G. (2010) 'Task completion competency and project management performance: the influence of control and user contribution', International Journal of Project Management, Vol. 28, No. 3, pp.220-227.

Mathrani, S. and Viehland, D. (2010) 'Critical success factors for the transformation process in enterprise system implementation', Proceedings of the 14th Pacific Asia Conference on Information Systems (PACIS, 2010), Taipei, 9-12 July, pp.821-831.

Muller, R. and Jugdev, K. (2012) 'Critical success factors in projects: Pinto, Slevin, and Prescott the elucidation of project success', International Journal of Managing Projects in Business, Vol. 5, No. 4, pp.757-775.

Nguyen, L.D., Ogunlana, S.O. and Xuan Lan, D.T. (2004) 'A study on project success factors in large construction projects in Vietnam', Engineering, Construction, and Architectural Management, Vol. 11, No. 6, pp.404-413.

Nidomolu, S. (1995) 'The effect of coordination and uncertainty on software project performance: residual performance risk as an intervening variable', Information Systems Research, Vol. 6, No. 3, pp.191-219.

Nixon, P., Harrington, M. and Parker, D. (2012) 'Leadership performance is significant to project success or failure: a critical analysis', International Journal of Productivity and Performance Management, Vol. 61, No. 2, pp.202-216. 
Pinto, J.K. and Mantel, S.J.J. (1990) 'The causes of project failure', IEEE Transactions on Engineering Management, Vol. 37, No. 4, pp. 269-277.

Pinto, J.K. and Prescott, J.E. (1988) 'Variations in critical success factors over the stages in the project life cycle', Journal of Management, Vol. 14, No. 1, pp.5-18.

Pinto, J.K. and Prescott, J.E. (1990) 'Planning and tactical factors in project implementation success', Journal of Management Studies, Vol. 27, No. 3, pp.305-328.

Pinto, J.K. and Slevin, D.P. (1987a) 'Balancing strategy and tactics in project implementation', Sloan Management Review, pp.33-41.

Pinto, J.K. and Slevin, D.P. (1987b) 'The critical factors in successful project implementation', IEEE Transactions on Engineering Management, Vol. 34, No. 1, pp.22-28.

Pinto, J.K. and Slevin, D.P. (1988a) 'Critical success factors in effective project implementation', in David, I.C. and William, R.K. (Eds): Project Management Handbook, 2nd ed., John Wiley \& Sons, NJ, pp.479-512.

Pinto, J.K. and Slevin, D.P. (1988b) 'Project success: definitions and measurement techniques', Project Management Journal, Vol. 19, No. 1, pp.67-73.

Pinto, J.K. and Slevin, D.P. (1988c) 'Critical success factors across the project life cycles', Project Management Journal, Vol. 19, No. 3, pp.67-75.

Plant, R. and Willcocks, L. (2007) 'Critical success factors in international ERP implementations: a case research approach', Journal of Computer Information Systems, Vol. 47, No. 3, pp.60-70.

PMI (2008) A Guide to the Project Management Body of Knowledge (PMBOK Guide), 4th ed., Project Management Institute, PA.

Poon, P. and Wagner, C. (2001) 'Critical success factors revisited: Success and failure cases of information systems for senior executives', Decision Support Systems, Vol. 30, No. 4, pp.393-418.

Prabhakar, G.P. (2008) 'What is project success: a literature review', International Journal of Business and Management, Vol. 3, No. 9, pp.3-10.

Radhakrishnan, S. (2010) 'IT offshore outsourcing in capital markets', Headstrong. Available online at: www.headstrong.com (accessed on 24 November 2011).

Ravichandran, T. and Rai, A. (2000) 'Quality management in systems development: an organizational systems perspective', MIS Quarterly, Vol. 24, No. 3, pp.381-415.

Remus, U. and Wiener, M. (2009) 'Critical success factors for managing offshore software development projects', Journal of Global Information Technology Management, Vol. 12, No. 1, pp.6-28.

Rose, J., Pedersen, K., Hosbond, J.H. and Kraemmergaard, P. (2007) 'Management competence, not tool and techniques: a grounded examination of software project management at WMdata', Information and Software Technology, Vol. 49, No. 6, pp.605-624.

Sauer, C. and Reich, B.H. (2009) 'Rethinking IT project management: evidence of a new mindset and its implications', International Journal of Project Management, Vol. 27, pp.182-193.

Shein, E. (1998) 'Prix fixe deals', PC Week, 27 July, Vol. 15, No. 30, pp.65-69.

Slevin, D.P. and Pinto, J.K. (1986) 'The project implementation profile: new tool for project managers', Project Management Journal, Vol. 17, No. 4, pp.57-70.

Smith, D.C., Bruyns, M. and Evans S. (2009) 'A project manager's optimism and stress management and IT project success', International Journal of Managing Projects in Business, Vol. 4, No. 1, pp.10-27.

Sudhakar, G.P. (2012) 'A model of critical success factors for software projects', Journal of Enterprise Information Management, Vol. 25, No. 6, pp.537-558.

TCS Annual Reports (2008-2013) Available online at: http://sites.tcs.com/investorsdocs/ TCS_Data_Sheet.xlsx (accessed on 30 June 2014).

The Standish Group (1994) The CHAOS Report, The Standish Group International, Inc., Boston, MA. 
Turner, J.R. and Muller, R. (2003) 'On the nature of the project as a temporary organization', International Journal of Project Management, Vol. 21, No. 1, pp.1-8.

Wateridge, J.F. (1995) 'IT Projects: a basis for success', International Journal of Project Management, Vol. 13, No. 3, pp.169-172.

Whittaker, B. (1999) 'What went wrong? Unsuccessful information technology projects', Information Management \& Computer Security, Vol. 7, No. 1, pp.23-29.

Wikipedia (2014) Global delivery model. Available online at: http://en.wikipedia.org/wiki/ Global_delivery_model (accessed on 7 July 2014).

Winter, M., Smith, C., Morris, P. and Cicmil, S. (2006) 'Directions for future research in project management: the main findings of a UK government-funded research network', International Journal of Project Management, Vol. 24, No. 8, pp.638-649.

Wipro Annual Reports (2008-2013) Available online at: http://www.wipro.com/investors/annualreports.aspx (accessed on 30 June 2014).

Wong, B. and Tein, D. (2004) 'Critical success factors for ERP projects', Australian Project Manager, Vol. 24, No. 1, pp.28-31.

Zwikael, O. (2008a) 'Top management involvement in project management: exclusive support practices for different project scenarios', International Journal of Managing Projects in Business, Vol. 1, No. 3, pp.387-403.

Zwikael, O. (2008b) 'Top management involvement in project management: a cross country study of the software industry', International Journal of Managing Projects in Business, Vol. 1, No. 4, pp.498-511.

Zwikael, O. and Globerson, S. (2006) 'From critical success factors to critical success processes', International Journal of Production Research, Vol. 44, No. 17, pp.3433-3449. 